\title{
SUBTIDAL EFFECTS OF A LARGE TYPHOON ON MIYAKE-JIMA, JAPAN
}

AUTHOR(S):

Tribble, Gordon W.; Bell, Lori J.; Moyer, Jack T.

\section{CITATION:}

Tribble, Gordon W....[et al]. SUBTIDAL EFFECTS OF A LARGE TYPHOON ON MIYAKE-JIMA, JAPAN. PUBLICATIONS OF THE SETO MARINE BIOLOGICAL LABORATORY 1982, 27(1-3): 110

ISSUE DATE:

1982-03-30

URL:

http://hdl.handle.net/2433/176048

RIGHT: 


\title{
SUBTIDAL EFFEGTS OF A LARGE TYPHOON ON MIYAKE-JIMA, JAPAN
}

\author{
Gordon W. TRIBBLE ${ }^{1)}$, LORI J. BELL and JAGK T. MOYER \\ Tatsuo Tanaka Memorial Biological Station, Ako, Miyake-jima, \\ Izu Islands, Japan 100-12
}

With Text-figure $1-2$ and Table $1-3$

\begin{abstract}
On October 19, 1979; a large typhoon passed within $160 \mathrm{~km}$ of the Japanese Island of Miyakejima. The typhoon generated surf in excess of $7 \mathrm{~m}$. A well known bay was surveyed after the storm, revealing significant effects in both the substrate and algal coverage. Disruption was most severe in the 5-10 m depth range; a shallower site was less affected. This may be a result of both large waves breaking farther offshore and the acclimation of shallow areas to typhoons as a result of previous storms of lower magnitude. Decreases in the abundance of 18 species of tropical reef fishes did not follow a depth dependent pattern and were thought to result from both mortality and displacement. It is hypothesized that strong differences in the level of reduction between species resulted from differential mortality due to spatial and behavioral differences between species.
\end{abstract}

\section{Introduction}

The effects of large storms on tropical marine communities have been documented. Robins (1957) noted 24 specimens representing 16 species of fish washed ashore at Key Biscayne, Florida, after a tropical storm in 1956. Banner (1961) described the reefs of Jaluit Atoll, Marshall Islands, following a large typhoon. Also, Stoddart (1962, 1965) described the damage and recovery of reefs at British Honduras after Hurricane Hattie, while Thomas et al. (1961) described the effects of Hurricane Donna on turtle grass beds. Moyer (1975) documented egg loss in the nest-guarding damselfish Pomacentrus nagasakiensis at Miyake-jima, Japan, after Typhoon 14 (1974). More recently, Randall and Eldredge (1977) described the effects of Typhoon Pamela on the shorelines and coral reefs of Guam. Kohn (in press) presents data on the effect of Hurricane Alice on intertidal gastropod populations at Enewetak Atoll. Dollar (in press) and Walsh (personal comm.) have surveyed the coral and fish communities, respectively, both before and after a large storm off Kona, Hawaii in 1980 . The effects of seasonal storms on subtidal and intertidal temperate algal communities were investigated by Lieberman et al. (1979) and Sousa (1979), respectively. However, the subtidal effects of a major typhoon or catastrophic storm in a nontropical area have not been documented (but see Moyer, 1975). In addition, most

1) Present address: 4074 Puu Eleele Pl., Honoulu, Hawaii 96816 USA.

Publ. Seto Mar. Biol. Lab., XXVII (1/3), 1-10, 1982.

(Article 1) 
typhoon work has been in the form of after-the-fact surveys, in which the prior state of the community was not. well known (but see Randall and Eldredge, 1977; Dollar, in press; Kohn, in press).

We present information on substrate changes, algal removal and changes in fish abundance and distribution at Igaya Bay, Miyake-jima $\left(35^{\circ} 05^{\prime} \mathrm{N}, 139^{\circ} 30^{\prime} \mathrm{E}\right)$, Japan, immediately following Typhoon Tip in October, 1979. In Japan, this storm was referred to as Typhoon 20. To our knowledge, this is the first published report of the subtidal effects of a large typhoon in a warm-temperate region. In addition, we have been able to assess the effects of the typhoon because the previous state of the community was well known.

\section{Methods}

Prior to Typhoon 20, we spent more than 2000 hours at Igaya Bay studying the behavior of reef fishes (eg. Moyer, 1975; Bell, 1976; Moyer and Bell, 1976; Moyer, 1977; Moyer and Nakazono, 1978; Moyer, 1979; Moyer, 1980; Moyer and Yogo, in press; Tribble, in press). The southern half of the bay has been used continuously

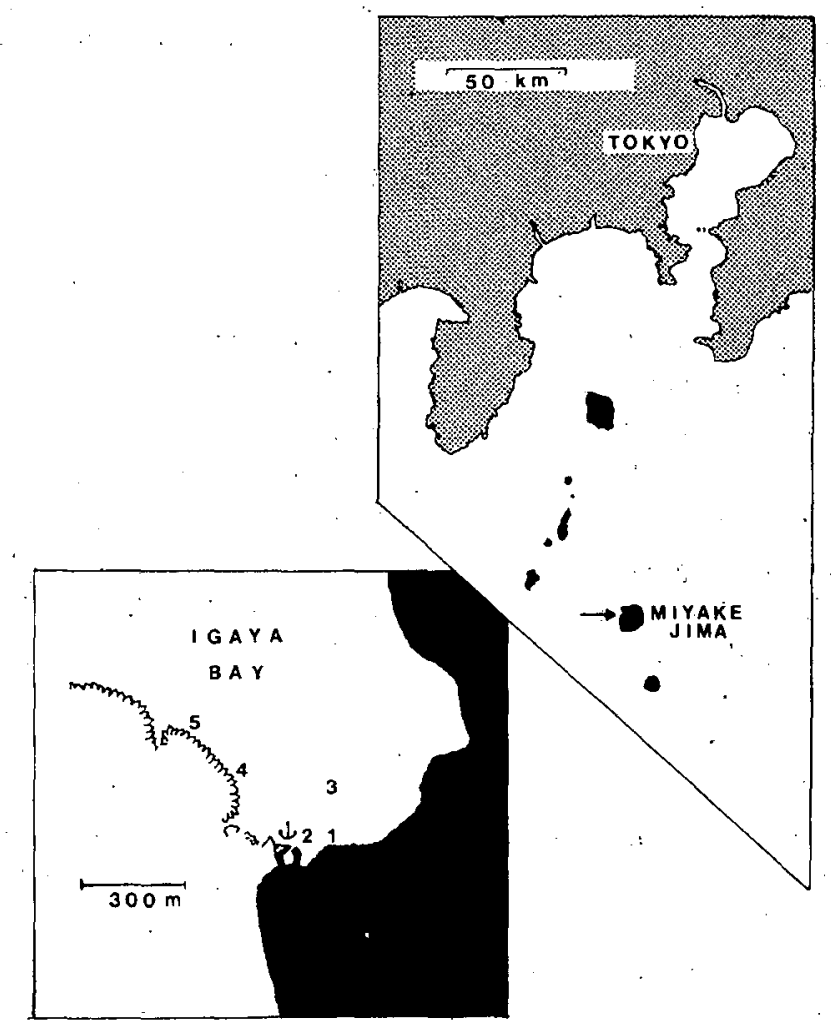

Fig. 1. Map of Igaya Bay and location of Miyake-jina. "The arrow at Miyake-jima indicates the location of Igaya Bay. The numbers in Igaya Bay correspond with the sites where typhoon effects were investigated. 
as a study area for the past 10 years, so the area as a whole is well known. The bay is located on the west coast of Miyake-jima and exposed to seas which prevail for most of the year (Fig. 1). However, it is somewhat sheltered in comparison with adjacent coastal areas.

Meteorological data were obtained from both the Joint Typhoon Warning Center, Guam, and the Japan Meteorological Agency. For the most part, we used data from the former source as it was readily available in published form, the Annual Typhoon Report (1979). Dates given in the present study coincide with calendar dates in Japan and other areas west of the international dateline.

The effects of Typhoon 20 were measured at five sites in Igaya Bay: 1-2 m deep at the upper subtidal zone (Site 1); an area $20 \mathrm{~m}$ offshore, $2-5 \mathrm{~m}$ deep, $50 \mathrm{~m}^{2}$ (Site 2); an area $200 \mathrm{~m}$ offshore towards the bay center, 10-12 $\mathrm{m}$ deep, $150 \mathrm{~m}^{2}$ (Site 3); and at 17 and $25 \mathrm{~m}$ deep along the base of a seaward running lava cliff, $1000 \mathrm{~m}^{2}$ (Site 4) and $300 \mathrm{~m}^{2}$ (Site 5), respectively.

Changes in the distribution and abundance of 18 species of reef fishes were measured in one of two ways, depending on what was initially known about their population. Nine of the species were subject to behavioral investigations prior to and after the storm. Members of these species were individually recognized by either distinct body markings or small body tags (Tribble, in press). Subsequent to the typhoon a survey was made of all sites to identify and count the remaining individuals. Changes in the abundance of most of the nine other species were determined by counting the number of individuals per cubic meter and multiplying by the total space occupied by each species. With few exceptions, individual fish were not recognized in these species so the results are probably less accurate than with the former method.

Vertical sand displacement and sizes of overturned rocks were measured with a calibrated line. Changes in the coverage of a predominant species of the folacious red algae Gelidium were roughly estimated by direct observation and reference to underwater photographs taken before and after Typhoon 20 .

Subtidal effects on the typhoon were measured from October 21 to December 31,1979 . On October 21 and 22, we performed only subjective surveys due to the murky water and rough conditions. The following week was spent censusing known individuals and groups of fish, in addition to measuring benthic changes. From that time until the end of the study, dives were made throughout the entire southern portion of the bay, encompassing, but not limited to, the five survey sites. A conscious effort was made to note any individually recognized fish displaced as a result of the typhoon during these dives.

\section{Results}

\section{Magnitude of the lyphoon}

Typhoon 20 was formally classified as a typhoon from October 6-20, 1979. It had wind speeds exceeding $165 \mathrm{knts}(85 \mathrm{~m} / \mathrm{sec})$, a minimum sea level pressure of $870 \mathrm{mb}$, and a circulation pattern with a radius of over $1000 \mathrm{~km}$. It had the 
largest diameter and lowest sea level pressure of any typhoon on record (Annual Typhoon Report, 1979).

Typhoon 20 passed within $160 \mathrm{~km}$ of Miyake-jima on October 19, 1979. Wave heights in excess of $7 \mathrm{~m}$ at southern and western parts of the island were estimated by the staff of the Miyake Branch of the Japan Meteorological Agency. Damage to fishing boats and coastal installations was extensive. Although accurate records are not available, it is considered by residents to be the worst storm in 62 years (Fig. 2).

A

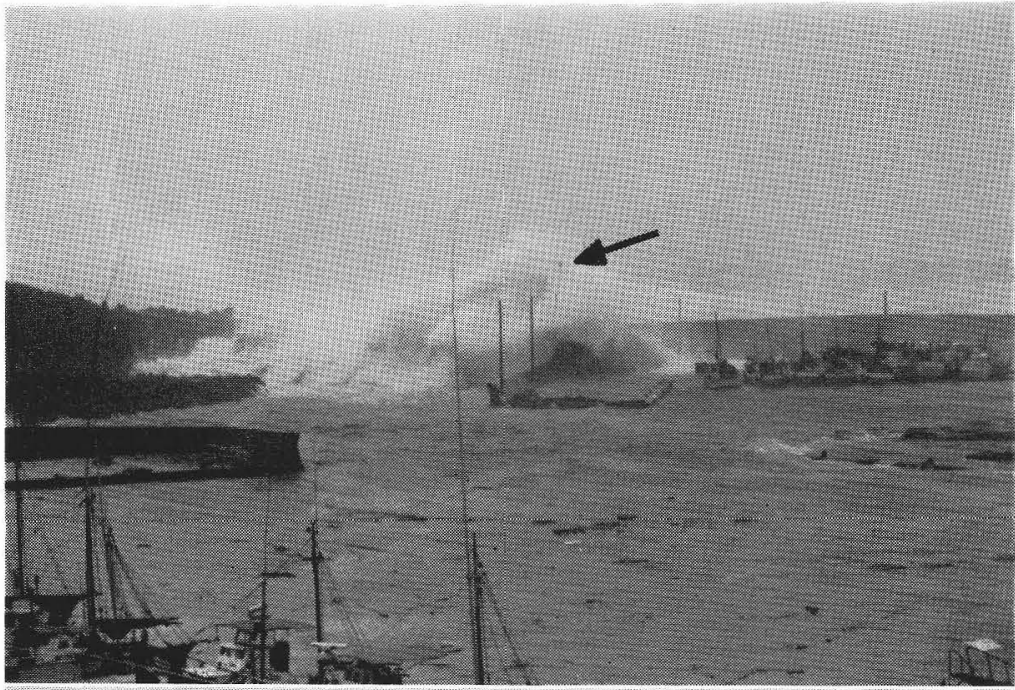

$\mathrm{B}$

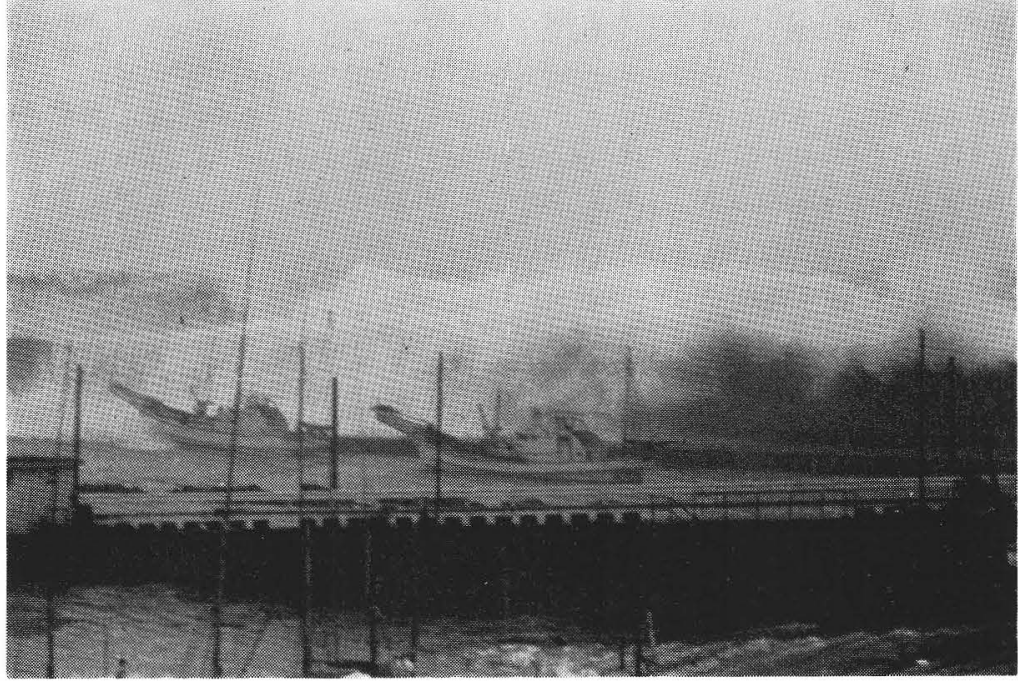

Fig. 2 'A'. Breaking surf at the entrance to Sabigahama harbor. The top of the lighthouse (arrow), on the breakwater, is $15 \mathrm{~m}$ above sea level.

' $\mathrm{B}$ '. Surf washing over the harbor breakwater, $7 \mathrm{~m}$ high. The fishing boats shown are about $25 \mathrm{~m}$ in total length. Photographs by N. Okiyama, October 19, 1979. 


\section{Benthic effects}

Prior to the typhoon, the upper subtidal zone, 1-2 m deep, was comprised mostly of rounded boulders $50-200 \mathrm{~cm}$ in diameter. Gelidium and encrusting corals were the predominant benthic organisms. Disruption to this habitat did not appear extreme. The largest displaced rock seen, $30 \mathrm{~cm}$ in diameter, was smaller than most rocks in this area. Also, Gelidium cover was only moderately reduced (Table 1).

The bottom $20 \mathrm{~m}$ offshore, $2-5 \mathrm{~m}$ deep, was previously comprised of a layer of small, loose cobble, about $10 \mathrm{~cm}$ in diameter. Boulders of varying sizes were also present. Illuminated rock surfaces not covered with live coral or Gelidium had a thin layer of microalgae. After the storm, this layer was absent, and Gelidium cover was reduced drastically (Table 1). Also, nearly all of the loose cobble appeared shifted or overturned. Rocks up to $75 \mathrm{~cm}$ in diameter were displaced.

Table 1. Gelidium coverage before and after Typhoon 20 estimated by direct observation.

\begin{tabular}{|c|c|c|c|c|}
\hline \multirow{2}{*}{ Area } & \multirow{2}{*}{ Depth } & \multicolumn{2}{|c|}{ Total Percent Cover } & \multirow{2}{*}{$\begin{array}{l}\text { Percent Reduction } \\
\text { of Cover }\end{array}$} \\
\hline & & Before & After & \\
\hline Upper Subtidal (Site 1) & $1-2 \mathrm{~m}$ & $30 \%$ & $20 \%$ & $33 \%$ \\
\hline 20 m Offshore (Site 2) & $2-5 \mathrm{~m}$ & $60 \%$ & $10 \%$ & $83 \%$ \\
\hline $200 \mathrm{~m}$ Offshore (Site 3 ) & $10-12 \mathrm{~m}$ & $50 \%$ & $10 \%$ & $80 \%$ \\
\hline Cliff Base (Site 4) & $17 \mathrm{~m}$ & $80 \%$ & $40 \%$ & $50 \%$ \\
\hline Cliff Base (Site 5) & $25 \mathrm{~m}$ & $30 \%$ & $20 \%$ & $33 \%$ \\
\hline
\end{tabular}

The bottom $200 \mathrm{~m}$ offshore, 10-12 $\mathrm{m}$ deep, was previously comprised of a patchwork of sand, loose cobble, and boulders. The green algae Codium covered approximately $5 \%$ of the bottom. As at the previous site, rock surfaces were thinly covered with a layer of microalgae. After Typhoon 20, rock surfaces were scoured, covered only by encrusting coralline algae. Codium was absent and Gelidium cover was highly reduced (Table 1); remaining algae were located chiefly on the lower sides and bases of large rocks. Rocks up to $40 \mathrm{~cm}$ in diameter were displaced and about $50 \%$ of the loose cobble was shifted. In sandy areas, $20-30 \mathrm{~cm}$ in depth of sand was displaced.

Before the typhoon, the lava cliff base consisted of lava and coral rubble with occasional boulders. A sandy plain bordered the outer edge. At a depth of $17 \mathrm{~m}$, storm action displaced up to $50 \mathrm{~cm}$ deep of sand in places. Sand $3 \mathrm{~m}$ deep was removed from one site at a depth of $10 \mathrm{~m}$, exposing a rocky ledge. Boulders up to $60 \mathrm{~cm}$ in diameter were overturned. At a depth of $25 \mathrm{~m}$ along the same cliff, storm effects were less evident. Few overturned rocks were seen; most debris appeared to be from the cliff top. Up to $30 \mathrm{~cm}$ deep of sand was displaced from the cliff base. Gelidium cover at the 17 and $25 \mathrm{~m}$ deep sites was reduced by about half (Table 1).

\section{Effects on resident fishes}

At Igaya Bay, Typhoon 20 markedly reduced the abundance of individually recognizable resident fish of nine species, with an average reduction of $46 \%$ per 
Table 2. Reduction of the abundance of individually recognizable resident fish (by color pattern or tags) after Typhoon 20.

Sites $\quad 2$ : $20 \mathrm{~m}$ offshore, $2-5 \mathrm{~m}$ deep $\left(50 \mathrm{~m}^{2}\right)$

3: $200 \mathrm{~m}$ offshore, $10-12 \mathrm{~m}$ deep $\left(150 \mathrm{~m}^{2}\right)$

7: Cliff base, $17 \mathrm{~m}$ deep $\left(1000 \mathrm{~m}^{2}\right)$

5: Cliff base, $25 \mathrm{~m}$ deep $\left(300 \mathrm{~m}^{2}\right)$

$\mathrm{N}_{1}=$ number of individuals present prior to Typhoon 20 .

$\mathrm{N}_{2}=$ number of individuals present after Typhoon 20 .

\begin{tabular}{llllll}
\hline \multicolumn{1}{c}{ Family } & \multicolumn{1}{c}{ Species } & $\mathrm{N}_{1}$ & $\mathrm{~N}_{2}$ & \% Reduction & Site \\
\hline Labridae (wrasses) & Coris dorsomaculata & 28 & 21 & 25 & 4,5 \\
& Macropharyngodon mojeri & 11 & 1 & 91 & 4 \\
& Pseudojuloides elongatus & 16 & 2 & 87 & 4 \\
& P. cerasinus & 14 & 1 & 93 & 4 \\
Pomacentridae (damselfishes) & Amphiprion clarkii & 20 & 13 & 35 & 2,3 \\
Pomacanthidae (angelfishes) & Centropyge interruptus & 46 & 41 & 11 & 4 \\
& C. tibicen & 11 & 10 & 9 & 3,4 \\
& C. vrolicki & 9 & 6 & 33 & $2,3,4$ \\
Ostraciidae (cowfishes) & Lactoria fornasini & 13 & 6 & 31 & 2 \\
\hline
\end{tabular}

species (Table 2). In addition, we calculated changes in the abundance of nine species, although distinct individuals were not recognized. The reduction of these fishes averaged $29 \%$ per species (Table 3 ). Eight dead fish observed in the bay after the typhoon included the moray eel Muraena pardalis $(\mathrm{n}=2)$, the butterflyfish Chaetodon nippon $(\mathrm{n}=1)$, the morwong Cheilodactylus zonatus $(\mathrm{n}=1)$, the cowfishes Lactoria diaphanus $(\mathrm{n}=2)$ and $L$. fornasini $(\mathrm{n}=1)$, and one small unidentifiable fish. One specimen of the angelfish Centropyge interruptus was found on a bluff $10 \mathrm{~m}$ from the beach.

The social and spatial organization of some fishes was affected by Typhoon 20. In the wrasse Coris dorsomaculata, six females changed social groups (Tribble, in press). Also, individuals of the normally territorial wrasse Pseudolabrus japonicus and damselfish Eupomacentrus altus were observed on October 21-22 swimming over wide areas

Table 3. Reduction of species with estimated population sizes before and after Typhoon 20. Sites: See Table 2

$\mathrm{N}_{1}=$ Estimated size of population prior to Typhoon 20.

$\mathrm{N}_{2}=$ Estimated size of population after Typhoon 20.

\begin{tabular}{llllll}
\hline \multicolumn{1}{c}{ Family } & \multicolumn{1}{c}{ Species } & $\mathrm{N}_{1}$ & $\mathrm{~N}_{2}$ & \% Reduction & Site \\
\hline Labridae (wrasses) & Cirrhilabrus temminckii & 175 & 40 & 77 & 4,5 \\
& Hologymnosus doliatus & 100 & 5 & 95 & 3,4 \\
& Pseudocoris yamashiroi & 100 & 90 & 10 & 5 \\
Pomacentridae (damsefishes) & Chromis flavomactlata & 1000 & 900 & 10 & $3,4,5$ \\
& C. chrysura & 100 & 90 & 10 & 3,5 \\
& C. albomaculata & 200 & 180 & 10 & 4,5 \\
& C. analis & 5 & 5 & 0 & 5 \\
Synodontidae (lizardifishes) & Synodus ulae & 150 & 30 & 80 & $2,3,4$ \\
Serranidae (groupers) & Anthias nobilis & 200 & 180 & 10 & 4,5 \\
\hline
\end{tabular}


without occupying an apparent territory. A group of the wrasse Cirrhilabrus temminckii $(n=5)$ was displaced from the cliff base toward the bay center, $150 \mathrm{~m}$ away. Finally, two adult angelfish Centropyge tibicen were found at an inshore area previously unoccupied by this species.

\section{Discussion}

The results indicate that Typhoon Tip had an obvious impact on the marine community. In terms of both algal cover and substrate changes, the greatest effects were at sites $20 \mathrm{~m}$ offshore (2-5 $\mathrm{m}$ deep) and $200 \mathrm{~m}$ offshore (10-12 $\mathrm{m}$ deep). With the exception of the upper subtidal site, the intensity of the disturbance decreased with increasing depth. The light effects of the storm on the upper subtidal area suggests that this area may be less susceptible to disruption. Prior to the typhoon, Gelidium cover was not high and the microalgal layer present in deeper water was absent. Hence, this habitat as a whole seems to have been more resistant to wave action. In addition, large waves, breaking in deeper water, may have dissipated some of their energy before reaching this shallow site.

The acclimation of the upper subtidal site may be a result of previous storms. Between September and November, 1979, three other storms hit Miyake-jima. Each produced surf in excess of $2.5 \mathrm{~m}$. Storms generating large surf occur 12-14 times a year. Also, from December to March yearly, gale force winds $(19.5 \mathrm{~m} / \mathrm{sec})$ are common on a weekly basis (Moyer, unpublished data).

Our observations are similar to findings of Randall and Eldredge (1977, personal comm.), who noted that the greatest submarine damage from Typhoon Pamela at Guam occurred at the reef slope, 5-10 $\mathrm{m}$ deep. The shallow reef flat was affected only superficially. They attributed these patterns to acclimation from previous storms and the dissipation of wave energy at the deeper reef slope.

The large scale absence of many known resident fishes after Typhoon 20 demonstrated that the storm had a great effect on the fish fauna of Igaya Bay. Changes in fish abundance were not as obviously depth-related as was the case with benthic disturbances, and the amount of reduction within a habitat varied greatly between species. Whether the absent fish died during the storm or ended up at sites outside the bay cannot be conclusively stated.

Some fish were displaced by the storm, and several known individuals were found outside of their previously occupied home ranges. Two reasons suggest that more territorial fish did not leave their home ranges for refuge in calmer water and may have died instead. First, the distribution of the displaced fish did not suggest an offshore movement to deeper, calmer water; displaced individuals of Cirrhilabrus temminckii found at Site 3 had previously lived in deeper water at Site 4 . Similarly, displaced individuals of Centropyge tibicen and Coris dorsomaculata were not found at deeper or less disturbed areas. Secondly, Igaya Bay is somewhat sheltered relative to adjacent coastal areas, with the general type of habitat found at the study sites being limited to the southern part of the bay. The area surrounding the seaward sides of 
the most offshore study sites, and extending past the mouth of the bay, is primarily sand with few rocks, coral or algae. Because of lack of shelter, it is unlikely that this habitat is suitable for the fish considered in this study.

Most individuals seen after Typhoon 20 were in essentially the same area that they occupied prior to the storm. If absent fish had simply ended up in locations outside the five survey sites, they would have been seen in other parts of the bay, which were frequented during other studies.

Robins (1957) suggested that fish killed by a tropical storm in Florida died from respiratory failure due to gill abrasion from high levels of suspended sediment. The hypothesis that fish died as a result of the combined effects of wave action and respiratory failure, considered in conjunction with spatial and, behavioral differences between species, might explain why some species were more severely affected than others. Fishes which live near the bottom, such as wrasses and lizardfish; would be exposed to particularly high levels of suspended sediment, especially as most of these fish.seek shelter by hiding in seaweed. Not surprisingly, these groups 'were among the most drastically reduced. Similarly, the anemonefish Amphiprion clarkii symbiotically takes shelter near sea anemones. These do not seem to be good shelters during a storm; two anemones and their symbiotic fish disappeared during Typhoon 20.

The angelfishes were only. slightly reduced (Table 2). These fish seek shelter deep in rock formations (Moyer and Nakazono, 1978) and were probably protected somewhat from the severe environmental conditions that prevailed during the storm. Interestingly, the three individuals of Centropyge vrolicki which were absent after the typhoon had previously lived in a large coral head which was broken and flipped over by the storm.

Midwater planktivores, such as Chromis spp., Anthias nobilis; and Pseudocoris yamashiroi (=Coris yamashiroi, Smith-Vaniz and Randall, MS) were relatively unaffected by the typhoon. This may be because they are adept at maintaining themselves in midwater. Also, because they tend to swim well off the bottom, they would have been exposed to lower levels of suspended particles. The midwater Chromis spp. surveyed are not highly territorial and have been observed moving. between sites. It is plausible that they sought refuge, temporarily, in deeper water.

The relatively high persistence of the cowfish Lactoria fornasini is an anomaly. These fish are notoriously weak swimmers (Hiatt and Strasburg; 1960) and are very site attached (Moyer, 1979).. Also, they lived in an area that.was affected severely by the typhoon. It is therefore hard to understand why this species was not affected more by Typhoon 20.

In contrast with our findings, Walsh (in prep.) noted little reduction in the abundance of fish after a large tropical storm hit Kona, Hawaii in 1980. He found that fish simply left their home ranges and sought refuge in deeper water. Our conflicting results may be due to differences in the topography of our study areas. In Kona, deepwater areas are closer inshore and offer more structural cover than the sandy, offshore areas of Igaya Bay. Shelter, as a major resource to reef fish, is 
limited to a small part of Igaya Bay. Thus, with no available refuge, it appears that high mortality of fish may have resulted from this typhoon.

\section{Acknowledgments}

We would like to thank the Miyake Branch of the Japan Meteorological Agency and the Joint Typhoon Warning Center, Guam, for their cooperation in providing meteorological data on Typhoon 20. We are grateful to Yutaka Yogo for the map of Igaya Bay, and to N. Okiyama for his photographs taken during the typhoon. Thanks are also due to Richard Randall for information on the subtidal effects of Typhoon Pamela in Guam, and to A. Kohn for his unpublished manuscript. In addition, conversations with Steve Ralston and Bill Walsh proved very fruitful and are deeply appreciated. Critical readings of earlier drafts of this paper by Kent Carpenter and Mark Hixon were very helpful. This in contribution No. 35, Tatsuo Tanaka Memorial Biological Station.

\section{LITERATURE GITED}

Annual Typhoon Report. 1979. Joint Typhoon Warning Center, Guam. 194 pp.

Banner, A.H. 1961. Submarine effects of the typhoon. Atoll Res. Bull. 75: 75-78.

Bell, L.J. 1976. Notes on the nesting success and fecundity of the anemonefish Amphiprion clarkii at Miyake-jima, Japan. Japan. J. Ichthyol. 22(4): 207-211.

Dollar, S.J. In press. Storm stress and coral community structure at Kona, Hawaii. 4th Int. Goral Reef Symp.

Hiatt, R.W. and D.W. Strasburg. 1960. Ecological relationships of the fauna on coral reefs on the Marshall Islands. Ecol. Monog. 30: 65-127.

Kohn, A.J. In press. Populations of tropical intertidal gastropods before and after a typhoon. Micronesica.

Lieberman, M., D.M. John, and D. Lieberman. 1979. Ecology of subtidal algae on seasonally devastated cobble substrates off Ghana. Ecol. 60(6): 1151-1161.

Moyer, J.T. 1975. Reproductive behavior of the damselfish Pomacentrus nagasakiensis at Miyake-jima, Japan. Japan. J. Ichthyol. 22(3): 151-163.

Moyer, J.T. 1977. Aggressive mimicry between juveniles of the snapper Lutijanus bohar and species of the damselfish genus Chromis from Japan. Japan. J. Ichthyol. 24(3): 218-222.

Moyer, J.T. 1979. Mating strategies and reproductive behavior of ostraciid fishes at Miyake-jima, Japan. Japan. J. Ichthyol. 26(2): 148-160.

Moyer, J.T. 1980. Influence of temperate waters on the behavior of the tropical anemonefish Amphiprion clarkii at Miyake-jima, Japan. Bull. Mar. Sci. 30: 261-272.

Moyer, J.T. and L.J. Bell. 1976. Reproductive behavior of the anemonefish Amphiprion clarkii at Miyake-jima, Japan. Japan. J. Ichthyol. 23(1): 23-32.

Moyer, J.T. and A. Nakazono. 1978. Population structure, reproductive behavior and protogynous hermaphroditism in the angelfish Centropyge interruptus at Miyake-jima, Japan. Japan. J. Ichthyol. $25(1): 25-39$.

Moyer, J.T. and Y. Yogo. In press. The lek mating system of Halichoeres melanochir (Pisces: Labridae) at Miyake-jima, Japan. Z. Tierpsychol.

Randall, R.H. and L.G. Eldredge. 1977. Effects of Typhoon Pamela on the coral reefs of Guam. Proc. Third Int. Coral Reef. Symp. (Univ. of Miami) 2: 525-531.

Robins, R.C. 1957. Effects of storms on the shallow water fish fauna of southern Florida with records of fish from Florida. Bull. Mar. Sci. 7(3): 76-78. 
Sousa, W.P. 1979. Disturbance in marine intertidal boulder fields: the nonequilibrium maintenance of species diversity. Ecol. 60(6): 1225-1239.

Stoddart, D.R. 1962. Catastrophic storm effects on the British Honduras reefs and cays. Nature 196(4854): 512-515.

Stoddart, D.R. 1965. Re-survey of hurricane effects on the British Honduras reefs and cays. Nature 207(4997): 589-592.

Thomas, L.P., D.R. Moore and R.C. Work. 1961. Effects of Hurricane Donna on the turtle grass beds of Biscayne Bay, Florida. Bull. Mar. Sci. Gulf Carrib. 11(2): 191-197.

Tribble, G.W. In press. Social organization, patterns of sexuality, and behavior of the wrasse Coris dorsomaculata at Miyake-jima, Japan. Env. Biol. Fish. 